\title{
Kehitysasteen ja säilöntäaineen vaikutus valkolupiini-vehnäsäilörehun käymislaatuun ja aerobiseen stabiilisuuteen
}

\author{
Walter König ${ }^{1}$, Laura Puhakka ${ }^{1}$, Marjukka Lamminen ${ }^{1}$, Kirsten Weiss ${ }^{2}$, Aila Vanhatalo ${ }^{1}$, Seija Jaak- \\ kola $^{1}$ \\ ${ }^{1)}$ Maataloustieteiden laitos, PL 28, Koetilantie 5, 00014 Helsingin yliopisto, walter.konig@ helsinki.fi \\ ${ }^{2)}$ U Berlin, Landwirtschaftlich-Gärtnerische Fakultät, Invalidenstraße 42, 10115 Berlin
}

\section{Tiivistelmä}

Palkoviljat voivat tehostaa kotimaista maidontuotantoa ja lisätä valkuaisrehujen omavaraisuutta. Lisäksi eri palkoviljalajeilla on tärkeä merkitys osana viljelykiertoa. Palkoviljasta voidaan hyödyntää pelkät siemenet tai koko kasvuston voi korjata kokoviljasäilörehuna. Palkoviljojen säilömistä vaikeuttaa kasvuston pieni kuiva-aine- ja sokeripitoisuus ja suuri puskurikapasiteetti. Tässä kokeessa tutkittiin valkolupiinin (Lupinus albus L.) säilöntää seoksena kevätvehnän kanssa.

Säilörehun raaka-aineena oli Ludic-valkolupiini ja Amaretto-kevätvehnä, jotka kasvatettiin seoksena. Rehut korjattiin kahdessa kasvuvaiheessa vehnän ollessa taikinatuleentumisen alussa (1) ja lopussa (2) 13. ja 27.8.2012. Niiton jälkeen kasvilajeista yhdistettiin kaksi seosta, joista toisessa oli 1/3 valkolupiinia $+2 / 3$ vehnää ja toisessa $2 / 3$ valkolupiinia $+1 / 3$ vehnää. Rehut säilöttiin ilman esikuivausta 1,5 litran laboratoriosiiloihin. Säilöntäainekäsittelyt olivat painorehu (PR) eli ei säilöntäainetta, muurahaishappo (MH) 4 l/tn 100 \%:na happona, natriumnitriitin ja heksamiinin (heksametyleenitetramiinin) seos $(\mathrm{NaHe}) 3 \mathrm{l} / \mathrm{tn}$ ja homofermentatiivinen maitohappobakteerivalmiste (LAB) 1x10 6 pmy/g. Siilot avattiin kolmen kuukauden säilönnän jälkeen, jolloin rehuista otettiin analyysinäytteet ja niiden aerobista stabiilisuutta mitattiin 12 päivän ajan.

Painorehun säilönnällinen laatu oli huono voihappokäymisen vuoksi. Suurimmat määrät mitattiin kasvuasteella 1 valkolupiinin osuuden ollessa 1/3. Voihappokäymisen vuoksi myös painorehun pH- ja ammoniakkiarvot olivat suuret ja jäännössokerin määrä pieni. Kaikki säilöntäainekäsittelyt paransivat rehun laatua painorehuun verrattuna, mutta säilöntäaineiden välillä oli selkeitä eroja. MHrehujen laatu oli huono, sillä kaikissa rehuissa esiintyi runsasta voihappokäymistä ja osassa rehuista pH oli kohonnut. NaHe-rehujen laatu oli hyvä, jota osoitti käymistuotteiden pienet pitoisuudet. Biologinen säilöntäaine (LAB) tuotti kasvuasteella 1 molemmista seoksista hyvää rehua ilman voihappoa. Sen sijaan kasvuasteen 2 rehujen laatu oli huono voihappokäymisen takia. pH-arvot olivat voihappokäymisestä huolimatta pieniä, mutta ammoniakkipitoisuudet olivat suuria. Etikkahapon pitoisuus oli kaikissa koerehuissa alle $20 \mathrm{~g} / \mathrm{kg}$ ka ja kaikki rehut olivat aerobisesti stabiileja.

Valkolupiini- kevätvehnäseoksen säilöntä on tämän kokeen perusteella haastavaa. Suurimmat voihappomäärät mitattiin painorehussa aikaisemman kasvuasteen seoksissa. Painorehun huono laatu oli odotettavissa rehukasvin säilöntäominaisuuksien takia. MH-rehujen laatu oli poikkeuksellisen huono vaikka $\mathrm{MH}$-käsittely laski rehumassan $\mathrm{pH}: n$ heti säilöntäainekäsittelyn yhteydessä erittäin alas (noin 3,6). LAB-käsittely toimi hyvin aikaisessa kehitysvaiheessa, mutta tulos oli huono myöhemmin korjatussa rehussa. Paras ja tasaisin rehun laatu saatiin NaHe-käsittelyllä. NaHe-rehujen laatu oli pienen voihappo-, etikkahappo- ja ammoniakkipitoisuuden perusteella hyvä vaikka $\mathrm{pH}$ olikin joissain rehuissa melko korkea.

Avainsanat: säilörehu, säilöntäaine, käymislaatu, aerobinen stabiilisuus, palkovilja, valkolupiini 


\section{Johdanto}

Palkokasvien viljely lisää kotimaisten valkuaisrehujen omavaraisuutta ja vähentää riippuvuutta typpilannoituksesta. Toimiva kasvinvuorotus ja maan kasvukunnon ylläpito edellyttää useiden eri typensitojakasvilajien käyttöä. Lupiinit (Lupinus) ovat hernekasveihin kuuluvia yksivuotisia palkokasveja. Eri lupiinilajeista viljellään rehuksi ainakin sini-, valko- ja keltalupiinia. Valkolupiini (Lupinus albus L.) tunnetaan hyvänä biomassan tuottajana kokoviljasäilörehuna (Azo ym. 2006) ja viherlannoituksessa. Valkolupiinin siemenet eivät ehdi valmistua Suomen kasvuoloissa, joten rehukäytössä tulee kyseeseen vain korjuu kokoviljasäilörehuna.

Puhtaan palkokasviviljelmän säilöntä on haastavaa suuren puskurikapasiteetin sekä pienen kuiva-aine- ja sokeripitoisuuden takia. Tämän vuoksi valkolupiinin viljely seoksena viljakasvien kanssa on tarpeen. Viljakasvuston puskurikapasiteetti on pienempi ja kuiva-ainepitoisuus suurempi ilman esikuivatusta sekä nurmiheinäkasveihin että palkokasveihin verrattuna. Taikinatuleentumisen alkuvaiheessa siinä on myös sokeria kohtuullisesti.

Happamuuteen perustava säilöntä edellyttää rehun pH:n laskua nopeasti tasolle, jolla voihappokäyminen ja muu virhekäyminen estyy. Säilöttävän kasvin suuri puskurikapasiteetti ja pieni vesiliukoisten sokerien pitoisuus vaikeuttavat $\mathrm{pH}: n$ laskua. Puskurikapasiteettiin vaikuttavat kasvin emäksiset kivennäisaineet, kasvihapot ja proteiinit, jotka sitovat happoa. Toisaalta pieni sokerimäärä ei riitä tarpeellisen maitohappomäärän tuottamiseen, kun säilöntä perustuu pelkästään käymiseen painorehussa tai biologisia säilöntäaineita käytettäessä. Kuiva-ainepitoisuuden ollessa pieni biologinen säilöntä on vaativaa. Biologisten säilöntäaineiden edut tulevat esille vasta, kun rehut voidaan esikuivata (Muck ja Kung 1997).

Vaihtoehto pH-laskuun perustuville säilöntäaineille on kemikaaliseos, joka sisältää natriumnitriittiä ja heksamiinia. Tämä seos estää suoraan kemikaalien avulla haittamikrobien toimintaa ja edistää näin luonnollisten maitohappobakteereiden toimintaa (Hellberg 1967). Säilönnällinen vaikutus ei perustu pH-laskuun vaan natriumnitriittin ja heksaminin bakteriosidiseen yhdysvaikutukseen haittamikrobeihin (Reuter ja Weissbach 1991). Heksamiinin hajoamisen välituote on formaldehydi, joka tuhoaa myös haittamikrobien itiöitä (Setlow 2006). Reuter ym. (1989) totesivat lukuisten kokeiden perusteella, että natriumnitriitin ja heksamiinin seoksella käsittelyt rehut lisäsivät voihappovapaiden rehujen määrää ja rehun vapaaehtoista syöntiä verrattuna muurahaishapolla käsiteltyihin rehuihin.

Tämän tutkimuksen tavoitteena oli tutkia kahdessa kehitysvaiheessa valkolupiinin säilöntää kokoviljasäilörehuksi seoksena kevätvehnän kanssa. Tutkimuksessa verrattiin kolmea erityyppistä säilöntäainetta.

\section{Aineisto ja menetelmät}

Koerehut tehtiin kesällä 2012 Viikin opetus- ja tutkimustilan Museopellon lohkolta. Valkolupiinin (Ludic) ja kevätvehnän (Amaretto) seos kylvettiin 10.5.2012. Kylvötiheys oli lupiinin siemeniä 36 $\mathrm{kpl} / \mathrm{m}^{2}$ ja vehnän siemeniä $360 \mathrm{kpl} / \mathrm{m}^{2}$. Lannoitusmäärä oli $60 \mathrm{~kg} \mathrm{~N} / \mathrm{ha}$. Kasvuston kehitystä hidasti melko viileä ja sateinen alkukesä. Koerehut tehtiin kahdessa kehitysvaiheessa 96 ja 110 päivää kylvön jälkeen. Niitto tehtiin sähkösaksilla ja sirpillä niittokorkeuden ollessa noin $8 \mathrm{~cm}$. Ensimmäisen korjuun aikana kasvuvaiheessa 1 (K1, 13.8.2012) kevätvehnä oli taikinatuleentumisen alussa ja toisen korjuun aikana kasvuvaiheessa 2 (K2, 27.8.2013) taikinatuleentumisen lopussa. Valkolupiinin palot olivat vihreitä ja kehittymässä niin, että ensimmäisessä korjuussa palon seinämät olivat pullistuneet hieman ja siemenet täyttivät $50 \%$ palkojen väliseinien välisestä tilasta (vaihe 4.2). Toisessa korjuussa siemenet täyttivät 75 \% väliseinien välisestä tilasta (vaihe 4.3) (Dracup ja Kirby 1996). Niiton jälkeen valkolupiini ja kevätvehnä lajiteltiin ja silputtiin erikseen näytesilppurilla. Kasvilajeista tehtiin kaksi seosta: $\operatorname{seos} 1$ (S1) 1/3 valkolupiinia $+2 / 3$ kevätvehnää tuorepainosta ja seos 2 (S2) 2/3 valkolupiinia $+1 / 3$ kevätvehnää tuorepainosta.

Säilöntäkokeessa käytettiin kolmea erilaista säilöntäainetta ja kontrollina oli painorehu (ei säilöntäainetta). Säilöntäaineet olivat muurahaishappo (MH) 4 litraa/t ilmaistuna $100 \%$ :na happona, maitohappobakteeri (LAB) Lactobacillus plantarum (DSM no 3676 ja 3677) 1000000 pesäkkeitä muodostavaa yksikköä (pmy)/g sekä natriumnitriitin $(0,75 \mathrm{~kg} / \mathrm{t}) \mathrm{ja}$ heksamiinia (heksametyleenitetramiini) $(0,5 \mathrm{~kg} / \mathrm{t}) \operatorname{seos}(\mathrm{NaHe})$. Natriumnitriitin ja heksamiinin käytön tavoitteena on estää suoraan klostridien toimintaa. Koerehut tehtiin 1,5 litran lasisiin laboratoriosiiloihin. Jokaisesta neljästä säilöntäkäsitte- 
lystä tehtiin kolme rinnakkaista siiloa. Säilöntäaineiden lisäyksen jälkeen raaka-ainemassasta mitattiin $\mathrm{pH}$.

Siilot avattiin 100 (kasvuaste 1) ja 101 (kasvuaste 2) päivää säilönnästä, jolloin niistä otettiin näytteet analyyseihin ja aerobisen stabiilisuuden määrittämistä varten. Rehuista analysoitiin kuivaaine, $\mathrm{pH}$, tuhka, typpi ja ammoniumtyppi Helsingin yliopistossa ja vesiliukoiset hiilihydraatit, maitohappo, haihtuvat rasvahapot ja alkoholit Saksassa Berliinin yliopistossa. Aerobisen stabiilisuuden mittauksessa rehunäyte laitettiin heti siilon avauksen jälkeen muovipussiin ja muovipussi styroksilaatikkoon. Sekä muovipussin että styroksilaatikon pohjassa oli aukko, jolla varmistettiin ilman virtaus rehun läpi. Laatikot säilytettiin 12 päivää kasvatuskaapissa 20 asteen lämpötilassa. Rehun lämpötila rekisteröitiin rehuun sijoitetuilla dataloggereilla.

Säilörehujen laatuparametrien tilastollinen testaus tehtiin erikseen neljän eri raaka-aineen rehuille (K1S1, K1S2, K2S1, K2S2). Normaalisti jakautuneet muuttujat testattiin varianssianalyysillä (SAS 9.3 Mixed proseduuri) ja käsittelyiden neliösumma jaettiin seuraaviin ortogonaalisiin kontrasteihin: 1) painorehu vs. säilöntäaineilla käsitellyt rehut 2) maitohappobakteereilla käsitelty LAB-rehu vs. kemiallisilla säilöntäaineilla valmistetut $\mathrm{MH}$ - ja NaHe-rehut ja 3) $\mathrm{MH}$-rehu vs. NaHe-rehu. Ei-normaalisti jakautuneet muuttujat testattiin ei-parametrisella Kruskall-Wallisin testillä (SPPS, versio 21) ja käsittelyiden erot selvitettiin parittaisella keskiarvotestillä.

\section{Tulokset ja tulosten tarkastelu}

Valkolupiinin kuiva-ainepitoisuus oli erittäin pieni molempina tekokertoina (taulukko 1). Toisella kerralla pitoisuutta vähensi myös hyvin sateinen sää juuri ennen rehuntekoa. Vehnän suuremman kuiva-ainepitoisuuden vuoksi säilöttyjen seosten kuiva-ainepitoisuus oli kuitenkin noin $300 \mathrm{~g} / \mathrm{kg}$, kun lupiinin osuus oli $1 / 3$ ja vastaavasti noin $220 \mathrm{~g} / \mathrm{kg}$ osuuden ollessa $2 / 3$. Sokeripitoisuuden perusteella ensimmäisen kehitysasteen seokset olivat kohtuullisen vaikeasti säilöttäviä ja toisen kehitysasteen seokset vaikeasti säilöttäviä.

Kaikki säilöntäainekäsittelyt paransivat rehun laatua painorehuun verrattuna, mutta säilöntäaineiden vaikutuksissa oli eroja. Säilöntäaineiden toimivuus oli myös osittain erilaisia eri raaka-aine-erissä kehitysasteen ja valkolupiinin osuuden vaihdellessa (taulukot 2 ja 3). Säilöntäaineiden välisissä vertailuissa tuli selvästi esiin valmisteiden erilaiset toimintaperiaatteet. Yhteinen piirre kaikille rehulle oli suhteellisen pieni etikkahapon määrä. Pitoisuus oli raaka-aine-erästä ja säilöntäaineesta riippumatta alle $15 \mathrm{~g} / \mathrm{kg}$ ka. Myös alkoholipitoisuudet olivat pieniä kaikissa muissa rehuissa paitsi K1S1 painorehussa. Kaikki rehut olivat myös aerobisesti täysin stabiileja 12 vuorokauden mittausaikana.

\section{Ei säilöntäainetta (painorehu) vs säilöntäaineet}

Valkolupiinin ja kevätvehnän seosten säilöntä oli tässä kokeessa hyvin haastavaa. Raaka-aine erästä riippumatta painorehun laatu oli huono, joka kuvastaa rehukasvin epäedullisia säilöntäominaisuuksia. Ensimmäisen kehitysasteen molempien seosten rehuissa painorehun laatu oli erittäin heikko arvioituna pH:n ja ammoniakki-, voihappo- sekä etanolipitoisuuden perusteella. Näiden laatuparametrien arvot olivat selvästi huonompi kuin säilöntäaineilla tehtyjen rehujen $(\mathrm{P}<0,001)$. Toisen kehitysasteen seoksissa painorehun $\mathrm{pH}$ oli lähellä neljää, mutta voihappo- ja ammoniakkipitoisuudet olivat edelleen suuria osoittaen rehun huonon laadun. Laatuparametrit eivät kuitenkaan toisella tekokerralla eronneet keskimäärin kaikilla säilöntäaineilla tehdyistä rehuista $(\mathrm{P}>0,05)$, koska myös $\mathrm{MH}$ - ja LAB-rehujen laatu oli huono ja voihappo- ja ammoniakkipitoisuudet suuria.

\section{Maitohappobakteeri vs kemialliset säilöntäaineet}

Biologisen säilöntäaineen tulos oli hyvä aikaisessa kehitysvaiheessa, mutta se tuotti huonoja tuloksia myöhemmin korjatussa rehussa. LAB-rehujen $\mathrm{pH}$ oli alempi (vähintään $\mathrm{P}<0,01$ ) kuin kemiallisilla säilöntäaineilla tehtyjen MH- ja NaHe-rehujen lukuun ottamatta K2S2-rehua. Alhainen LAB-rehujen pH oli seurausta riittävästä maitohappokäymisestä, jonka seurauksena maitohappopitoisuus oli edellä 
mainituissa rehuerissä suurempi ja sokeripitoisuus pienempi kuin $\mathrm{MH}$ - ja NaHe-rehujen $(\mathrm{P}<0,01)$. Voihappoa esiintyi toisen kehitysvaiheen LAB-rehuissa määriä (1,9 ja 1,6 g/kg tuoretta rehua), jotka ylittävät hyvälaatuisessa rehun raja-arvon $(1 \mathrm{~g} / \mathrm{kg})$. Ero keskimäärin $\mathrm{MH}$ - ja NaHe-rehuihin ei ollut merkitsevä, koska myös MH-rehussa esiintyi suuria pitoisuuksia voihappoa.

\section{Muurahaishappo vs natriumnitriitti + heksamiini}

Kemiallisten säilöntäaineiden keskinäisessä vertailussa ensimmäisen kehitysasteen $\mathrm{MH}$-rehujen $\mathrm{pH}$ oli matalampi kuin $\mathrm{NaHe}$ rehujen $(\mathrm{P}<0,01)$. Toisessa kehitysvaiheen S1-rehuissa MH-rehun $\mathrm{pH}$ oli korkeampi $(\mathrm{P}<0,001)$ kuin NaHe-rehun, mutta S2-rehuissa ei ollut merkitsevää eroa. Rehunteon yhteydessä muurahaishappo laski raaka-ainemassan pH:n tehokkaasti alas sen ollessa noin 3,6 kaikissa neljässä rehuerässä. Alhainen $\mathrm{pH}$ ei kuitenkaan säilynyt vaan MH-rehujen pH:t olivat kohonneet lähtötilanteesta.

Molemmat kemialliset säilöntäaineet rajoittivat käymistä, jonka vuoksi rehujen sokeripitoisuuksissa ei ollut eroja missään rehuerässä. Maitohapon määrä oli kuitenkin NaHe-rehuissa suurempi $(\mathrm{P}<0,001)$ lukuun ottamatta K1S2-rehuja. Toisaalta keskimääräinen MH-rehun voihappopitoisuus oli kaikissa rehuerissä selvästi suurempi kuin NaHe-rehun. Ero oli kuitenkin merkitsevä ainoastaan K2S1rehuissa $(\mathrm{P}<0,001)$ johtuen rinnakkaissiilojen suuresta vaihtelusta muissa raaka-aine-erissä. K1S2rehuja lukuunottamatta $\mathrm{MH}$-rehujen käymishappopitoisuus oli merkitsevästi pienempi kuin $\mathrm{NaHe}$ rehujen $(\mathrm{P}<0,05)$. Samalla maitohapon osuus käymishapoista oli $\mathrm{MH}$-rehuissa $\mathrm{NaHe}$-rehuja pienempi eron ollessa merkitsevä K2-rehuissa.

Ammoniakkipitoisuus oli NaHe-rehuissa suurempi kuin MH-rehuissa ensimmäisessä kehitysasteessa $(\mathrm{P}<0,05)$. Toisen kehitysasteen rehuissa erot eivät olleet merkitseviä. Kun $\mathrm{NaHe}-$ säilöntäaineessa lisättyjen typpiyhdisteiden oletettiin hajoavan kokonaan ammoniakiksi, oli K1S1 rehuissa laskennallisesti korjattu ammoniakkitypen osuus NaHe-rehussa pienempi kuin $\mathrm{MH}$-rehussa $(\mathrm{P}<0,05)$. Muissa rehuerissä erot eivät olleet merkitseviä.

MH-rehujen laatu oli yllättävän huono. Rehun raaka-aineen nopeasta $\mathrm{pH}: n$ laskusta huolimatta voihappoa esiintyi kaikissa MH-rehuissa yli hyvän rehun laaturajan. Rehujen pH-arvo nousi säilönnän aikana niin, että suurin $\mathrm{pH}$ mitattiin kasvuasteella 2 seoksen 1 rehussa $(\mathrm{pH} 4,69)$. Muurahaishapon antimikrobinen vaikutus perustuu ei-dissosioituneeseen happomolekyyliin. Muurahaishapon $\mathrm{pk}_{\mathrm{a}}$-arvo on 3,78. Tällä pH-tasolla $50 \%$ muurahaishapon molekyyleistä on dissosioinut. Tämän perusteella tässä kokeessa muurahaishapon bakteriosidinen vaikutus ei ollut riittävä korkean $\mathrm{pH}: n$ takia. Säilövä vaikutus perustui todennäköisesti enemmän happovaikutukseen, joka kuitenkaan ei ollut riittävä.

MH-rehujen huonoon säilönnälliseen laatuun saattoi toisaalta vaikuttaa nimenomaan rehun nopea pH-lasku säilöntäaineen lisäyksen yhteydessä. Säilönnän alkuvaiheessa toimivat enterobakteerit muuttavat osan kasvin nitraattista nitriitiksi, joka estää klostridien kasvua. Kun rehun pH-laskee nopeasti, enterobakteereiden toiminta estyy (McDonald ym. 1991). Myös Kaiser ym. (2005) totesivat, että tuoreessa rehussa tarvitaan alhaisen $\mathrm{pH}: n$ lisäksi suoraan klostridien aktivisuuteen vaikuttava inhibiittori. Paras ja tasaisin rehun laatu saavutettiin NaHe-käsittelyllä. NaHe-rehujen laatu oli hyvä vaikka rehun $\mathrm{pH}$ oli joissain rehuissa melko korkea. NaHe:n kemialliset säilöntäaineet vaikuttavat suoraan haittamikrobeihin ja laatu ei ollut samalla tavalla sidoksissa $\mathrm{pH}$-arvoon kuten muissa rehuissa.

\section{Johtopäätökset}

Koerehuissa todetun voihappokäymisen perusteella raaka-aineessa oli voihappoitiöitä. Tämä siitäkin huolimatta, että raaka-aine kerättiin hyvin puhtaana. Kokoviljatyyppinen rehun raaka-aine saattaa olla enemmän altis voihappoitiökontaminaatiolle kuin nurmirehu.

Raaka-aineen vaikean säilöttävyyden vuoksi voihappobakteereiden toiminnan estäminen ei onnistunut ilman säilöntäainetta eikä myöskään kaikkien säilöntäaineiden avulla. Huolimatta vehnän paremmista säilöntäominaisuuksista valkolupiiniin verrattuna, vehnän runsaampikaan käyttö seoksessa ei parantanut riittävästi säilöttävyyttä kaikkien säilöntäaineiden toimivuuden kannalta.

Maitohappobakteereihin perustuva säilöntäaine toimi hyvin vain aikaisemmassa kehitysvaiheessa, kun raaka-aineessa oli enemmän sokeria. Sokeri ja maitohappokäyminen mahdollistivat rehun pH:n laskun riittävän alas voihappokäymisen estämiseksi. 
Muurahaishapon suora happovaikutus ei ollut riittävä laskemaan $\mathrm{pH}: t a$ pysyvästi tarpeeksi alas voihappokäymisen estämiseksi. Käytetty annostus esti toisaalta maitohappobakteerien toiminnan ja maitohapon muodostumisen, joka olisi osaltaan voinut ylläpitää alhaista pH:ta.

Natriumnitriitin ja heksamiinin seoksen toiminta perustuu suoraan haittamikrobien toiminnan estoon, jonka seurauksena rehuissa ei esiintynyt juuri lainkaan voihappoa. Valmiste esti osassa rehuista myös maitohappobakteereiden toimintaa ja maitohapon tuotantoa, jolloin rehun $\mathrm{pH}$ jäi melko korkealle. Kokeen perusteella $\mathrm{pH}$ ei ole sopiva laatukriteeri arvioitaessa natriumnitriitin ja heksamiinin seoksella käsiteltyjen rehujen laatua.

\section{Kirjallisuus}

Azo, W.M., Lane, G.P.F., Davies, W.P. \& Cannon, N.D. 2012. Bi-cropping white lupins (Lupinus albus L.) with cereals for wholecrop forage in organic farming: The effect of seed rate and harvest dates on crop yield and quality. Biological Agriculture \& Horticulture 28: 86-100.

Dracup, M. \& Kirby, E. J. M. 1996. Lupin development quide. University of Western Australia Press. 97 p.

Hellberg, A. 1967. A combination of nitrite and hexamine as an additive $\mathrm{n}$ the ensiling of herbage. Journal of the British Grassland Society 22:289-297

Kaiser, E., Weiss, K. \& Polip, I 2005. New results on inhibition of clostridia development in silages. Silage production and utilisation. Proceedings of the XIVth international Silage Conference, Belfast, Nothern Ireland. Ed. by: Park, R. S. \& Stronge, M. D.

McDonald, P., Henderson, A R. \& Heron, S. J. E. 1991. The Biochemistry of Silage. 2nd edition. Chalcombe Publications, Marlow, UK. 340 p.

Muck, R. E., and Kung, L. Jr. 1997. Effects of silage additives on ensiling.p.187-199. In Silage: Field to feedbunk. NRAES-99. Proc. North American Conf. Hershley, PA. 11-13 Feb. Northeast Reg. Agric. Eng. Serv., Coop. Ext., Ithaca, NY.

Reuter, B., Weissbach, F., Schmidt, L. \& Zwierz, P. M. 1989. Investigation on the efficiency of the silage additive Cekafusil. P.69-78. In F.Weissbach (ed) Proc. Int. Symp. Prod. Eval. Feeding Silage. Berlin, Germany. Druckerei, Berlin.

Reuter, B., \& Weissbach, F. 1991. Results of testing chemical preservatives. Pages 338-341 in Proc. of a Conf. on Forage Conservation towards 2000. G. Pahlow and H. Honig, ed. Institute of Grassland and Forage Research, Federal Research Center of Agriculture (FAL), Braunschweig, Germany

Setlow, P. 2006 Spores of Bacillus subtilis. Their resistance to and killing by radiation, heat and chemicals. Journal of Applied Microbiology 101:514-525

Taulukko 1. Raaka-aineiden koostumus (g/kg ka, jos muuta ei mainittu). Seoksessa 1 valkolupiinin ja kevätvehnän suhde 1:2 ja seoksessa 2 suhde 2:1 tuorepainosta.

\begin{tabular}{|c|c|c|c|c|c|c|c|c|}
\hline & \multicolumn{4}{|c|}{ Kehitysaste 1} & \multicolumn{4}{|c|}{ Kehitysaste 2} \\
\hline & $\begin{array}{l}\text { Valko- } \\
\text { lupiini }\end{array}$ & $\begin{array}{l}\text { Kevät- } \\
\text { vehnä }\end{array}$ & Seos 1 & Seos 2 & $\begin{array}{l}\text { Valko- } \\
\text { lupiini }\end{array}$ & $\begin{array}{l}\text { Kevät- } \\
\text { vehnä }\end{array}$ & Seos 1 & Seos 2 \\
\hline \multicolumn{9}{|l|}{ Kuiva-aineesta, \% } \\
\hline Valkolupiini & & & 17,7 & 46,2 & & & 16,1 & 43,4 \\
\hline Kevätvehnä & & & 82,3 & 53,8 & & & 83,9 & 56,6 \\
\hline Kuiva-aine, g/kg & 163 & 379 & 307 & 235 & 138 & 359 & 285 & 212 \\
\hline Tuhka & 70,2 & 96,2 & 91,6 & 84,2 & 68,7 & 88,1 & 85,0 & 79,7 \\
\hline Raakavalkuainen & 184 & 71 & 91 & 123 & 182 & 61 & 81 & 114 \\
\hline NDF & 390 & 520 & 497 & 460 & 436 & 525 & 510 & 486 \\
\hline Sokeri & 126 & 84 & 91 & 103 & 84 & 35 & 43 & 56 \\
\hline Tärkkelys & 30 & 183 & 152 & 113 & 23 & 255 & 218 & 154 \\
\hline Liukoinen $\mathrm{N}, \mathrm{g} / \mathrm{kg} \mathrm{N}$ & 360 & 658 & 605 & 520 & 361 & 610 & 570 & 502 \\
\hline Puskurik., mekv/kg ka & 709 & 297 & 370 & 488 & 687 & 296 & 359 & 466 \\
\hline D-arvo ${ }^{11}$ & 622 & 580 & 587 & 599 & 599 & 584 & 586 & 591 \\
\hline
\end{tabular}

1) D-arvo laskettu orgaanisen aineen in vitro -sellulaasiliukoisuuden perusteella käyttämällä kokoviljasäilörehun laskentakaavaa 
Taulukko 2. Säilöntäaineen vaikutus rehun koostumukseen ja säilönnälliseen laatuun ensimmäisessä kehitysvaiheessa (g/kg kuiva-ainetta, jos ei muuta mainittu). Seoksessa 1 valkolupiinin ja kevätvehnän suhde 1:2 ja seoksessa 2 suhde 2:1 tuorepainosta.

\begin{tabular}{|c|c|c|c|c|c|c|c|c|}
\hline & \multicolumn{4}{|c|}{ Säilöntäaineet ${ }^{1}$} & \multirow[b]{2}{*}{ SEM } & \multicolumn{3}{|c|}{ Tilastollinen merkitsevyys } \\
\hline & PR & MH & $\mathrm{NaHe}$ & LAB & & $\begin{array}{c}\text { PR } \\
\text { vs } \\
\text { muut }\end{array}$ & $\begin{array}{l}\text { LAB vs } \\
\mathrm{MH} \text { ja } \\
\mathrm{NaHe}\end{array}$ & $\begin{array}{l}\mathrm{MH} \\
\text { vs } \\
\mathrm{NaHe} \\
\end{array}$ \\
\hline \multicolumn{9}{|l|}{ Seos 1} \\
\hline Kuiva-aine, $\mathrm{g} / \mathrm{kg}$ & 290 & 311 & 313 & 309 & 6,3 & 0,020 & 0,677 & 0,801 \\
\hline Tuhka & 91,6 & 82,4 & 79,1 & 79,3 & 1,88 & $<0,001$ & 0,537 & 0,249 \\
\hline Raakavalkuainen & 102 & 91,8 & 91,0 & 95,4 & 2,09 & 0,004 & 0,158 & 0,794 \\
\hline $\mathrm{pH}$ & 4,53 & 4,28 & 5,01 & 3,75 & 0,028 & $<0,001$ & $<0,001$ & $<0,001$ \\
\hline Sokeri & 29,2 & 109 & 113 & 23,9 & 5,70 & $<0,001$ & $<0,001$ & 0,622 \\
\hline Maitohappo & 32,5 & 2,9 & 17,2 & 53,0 & 1,92 & 0,006 & $<0,001$ & $<0,001$ \\
\hline Etikkahappo & 3,24 & 4,59 & 10,48 & 4,75 & 0,417 & $<0,001$ & $<0,001$ & $<0,001$ \\
\hline Voihappo & $37,69^{\mathrm{a}}$ & $6,01^{\mathrm{ab}}$ & $0,00^{\mathrm{b}}$ & $0,00^{\mathrm{b}}$ & 1,297 & \multicolumn{3}{|c|}{ Ei normaalisti jakautunut } \\
\hline VFA yhteensä & 42,8 & 11,1 & 10,5 & 4,75 & 1,42 & $<0,001$ & 0,008 & 0,773 \\
\hline Hapot yhteensä ${ }^{3}$ & 75,4 & 13,9 & 27,7 & 57,7 & 2,91 & $<0,001$ & $<0,001$ & 0,010 \\
\hline Etanoli & 25,23 & 3,78 & 2,32 & 6,37 & 0,554 & $<0,001$ & 0,001 & 0,100 \\
\hline Muut alkoholit ${ }^{4}$ & 2,76 & 1,30 & 1,82 & 1,30 & 0,115 & $<0,001$ & 0,103 & 0,013 \\
\hline Amm. N, g/kg N & 188 & 66 & 107 & 62 & 5,2 & $<0,001$ & 0,005 & $<0,001$ \\
\hline Amm. N, g/kg N ${ }^{2}$ & 188 & 66 & 25 & 62 & 5,0 & $<0,001$ & 0,025 & $<0,001$ \\
\hline \multicolumn{9}{|l|}{ Seos 2} \\
\hline Kuiva-aine, $\mathrm{g} / \mathrm{kg}$ & 226 & 237 & 240 & 245 & 4,1 & 0,016 & 0,238 & 0,556 \\
\hline Tuhka & 84,5 & 75,6 & 75,4 & 73,3 & 1,76 & 0,001 & 0,333 & 0,928 \\
\hline Raakavalkuainen & 125 & 119 & 107 & 114 & 3,15 & 0,013 & 0,804 & 0,028 \\
\hline $\mathrm{pH}$ & 4,60 & 4,06 & 4,67 & 3,83 & 0,094 & 0,005 & 0,002 & 0,002 \\
\hline Sokeri & 14,2 & 87,2 & 112 & 21,3 & 17,1 & 0,017 & 0,006 & 0,335 \\
\hline Maitohappo & 45,9 & 24,9 & 38,4 & 75,3 & 7,54 & 0,974 & 0,002 & 0,244 \\
\hline Etikkahappo & 7,23 & 6,79 & 11,71 & 7,27 & 0,718 & 0,140 & 0,054 & 0,001 \\
\hline Voihappo & 43,09 & 9,32 & 0,54 & 0,00 & 3,201 & $<0,001$ & 0,244 & 0,089 \\
\hline VFA yhteensä & 55,1 & 19,2 & 12,5 & 7,27 & 4,69 & $<0,001$ & 0,173 & 0,344 \\
\hline Hapot yhteensä ${ }^{3}$ & 101 & 44,2 & 50,9 & 82,6 & 10,1 & 0,007 & 0,022 & 0,649 \\
\hline Etanoli & 28,3 & 5,92 & 5,42 & 12,9 & 0,001 & $<0,001$ & 0,004 & 0,815 \\
\hline Muut alkoholit ${ }^{4}$ & 4,95 & 3,33 & 3,56 & 3,16 & 0,411 & 0,010 & 0,583 & 0,711 \\
\hline Amm. N,g/kg N & 241 & 64 & 127 & 60 & 10,3 & $<0,001$ & 0,023 & 0,003 \\
\hline Amm. N,g/kg N ${ }^{2}$ & 241 & 64 & 37 & 60 & 10,3 & $<0,001$ & 0,480 & 0,104 \\
\hline
\end{tabular}

\footnotetext{
${ }^{1} \mathrm{PR}=$ ei säilöntäainetta (painorehu), $\mathrm{MH}=$ muurahaishappo, $\mathrm{NaHe}=$ heksametyleenitetramiinin ja natriumnitriitin seos, $\mathrm{LAB}=$ maitohappobakteeri Lactobacillus plantarum

${ }^{2}$ Vähennetty säilöntäaineessa lisätty typpi. Kaikki säilöntäaineessa lisätty $\mathrm{N}$ on laskettu korjatussa pitoisuudessa ammoniakkitypeksi, koska tarkkaa tietoa muuntumisosuudesta ei ole käytettävissä.

${ }^{3}$ Maitohappo+haihtuvat rasvahapot (etikka-, propioni-, isovoi-, voi-, isovaleriaana-, valeriaana- ja kapronihappo)

${ }^{4}$ Muut alkoholit: metanoli, propanoli, butanoli
} 
Taulukko 3. Säilöntäaineen vaikutus rehun koostumukseen ja säilönnälliseen laatuun toisessa kehitysvaiheessa ( $\mathrm{g} / \mathrm{kg}$ kuiva-ainetta, jos ei muuta mainittu). Seoksessa 1 valkolupiinin ja kevätvehnän suhde 1:2 ja seoksessa 2 suhde 2:1 tuorepainosta.

\begin{tabular}{|c|c|c|c|c|c|c|c|c|}
\hline & \multicolumn{4}{|c|}{ Säilöntäaineet ${ }^{1}$} & \multicolumn{4}{|c|}{ Tilastollinen merkitsevyys } \\
\hline & PR & $\mathrm{MH}$ & $\mathrm{NaHe}$ & LAB & SEM & $\begin{array}{c}\text { PR } \\
\text { vs } \\
\text { muut }\end{array}$ & $\begin{array}{c}\text { LAB vs } \\
\mathrm{MH} \mathrm{ja} \\
\mathrm{NaHe}\end{array}$ & $\begin{array}{c}\mathrm{MH} \\
\text { vs } \\
\mathrm{NaHe} \\
\end{array}$ \\
\hline \multicolumn{9}{|l|}{ Seos 1} \\
\hline Kuiva-aine, g/kg & 315 & 311 & 317 & 327 & 5,3 & 0,583 & 0,090 & 0,434 \\
\hline Tuhka & 67,1 & 73,5 & 68,1 & 66,4 & 1,25 & 0,165 & 0,022 & 0,016 \\
\hline Raakavalkuainen & 85,4 & 86,7 & 82,1 & 83,5 & 1,95 & 0,586 & 0,710 & 0,138 \\
\hline $\mathrm{pH}$ & 4,05 & 4,69 & 4,20 & 4,08 & 0,047 & 0,001 & $<0,001$ & $<0,001$ \\
\hline Sokeri & 12,7 & 33,6 & 39,1 & 15,0 & 2,26 & $<0,001$ & $<0,001$ & 0,125 \\
\hline Maitohappo & 41,9 & 3,8 & 32,7 & 34,7 & 2,37 & $<0,001$ & $<0,001$ & $<0,001$ \\
\hline Etikkahappo & 6,37 & 4,85 & 9,36 & 4,26 & 1,103 & 0,873 & 0,068 & 0,020 \\
\hline Voihappo & 4,44 & 11,6 & 0,00 & 5,69 & 1,526 & 0,475 & 0,960 & $<0,001$ \\
\hline VFA yhteensä & 10,8 & 21,9 & 9,4 & 10,0 & 1,71 & 0,178 & 0,027 & $<0,001$ \\
\hline Hapot yhteensä ${ }^{3}$ & 52,7 & 25,6 & 42,0 & 44,6 & 3,12 & 0,003 & 0,022 & 0,006 \\
\hline Etanoli & 5,80 & 3,99 & 1,61 & 4,35 & 0,005 & 0,002 & 0,003 & 0,009 \\
\hline Muut alkoholit $^{4}$ & 1,25 & 0,96 & 1,64 & 1,20 & 0,07 & 0,834 & 0,274 & $<0,001$ \\
\hline Amm. N, g/kg N & 129 & 128 & 124 & 107 & 7,5 & 0,298 & 0,069 & 0,728 \\
\hline Amm. N, g/kg N ${ }^{2}$ & $129^{\mathrm{a}}$ & $128^{\mathrm{ab}}$ & $36^{\mathrm{b}}$ & $107^{\mathrm{ab}}$ & 7,3 & \multicolumn{3}{|c|}{ Ei normaalisti jakautunut } \\
\hline \multicolumn{9}{|l|}{ Seos 2} \\
\hline Kuiva-aine, g/kg & 218 & 226 & 229 & 245 & 9,5 & 0,200 & 0,175 & 0,857 \\
\hline Tuhka & 63,2 & 75,8 & 72,6 & 73,2 & 2,16 & 0,003 & 0,711 & 0,321 \\
\hline Raakavalkuainen & 112 & 109 & 106 & 102 & 4,85 & 0,281 & 0,423 & 0,655 \\
\hline $\mathrm{pH}$ & 3,93 & 4,20 & 3,96 & 4,00 & 0,146 & 0,501 & 0,693 & 0,279 \\
\hline Sokeri & 15,3 & 65,9 & 30,5 & 13,4 & 8,82 & \multicolumn{3}{|c|}{ Ei normaalisti jakautunut } \\
\hline Maitohappo & 70,4 & 5,1 & 57,8 & 45,8 & 8,41 & 0,008 & 0,201 & 0,002 \\
\hline Etikkahappo & 10,3 & 8,3 & 11,7 & 13,4 & 2,40 & 0,770 & 0,286 & 0,347 \\
\hline Voihappo & 5,16 & 8,70 & 0,43 & 6,51 & 3,992 & 0,991 & 0,700 & 0,181 \\
\hline VFA yhteensä & 15,5 & 23,5 & 12,5 & 20,3 & 6,85 & 0,690 & 0,788 & 0,290 \\
\hline Hapot yhteensä ${ }^{3}$ & 85,8 & 28,5 & 70,2 & 66,1 & 9,80 & 0,026 & 0,202 & 0,017 \\
\hline Etanoli & 11,3 & 3,41 & 3,57 & 7,55 & 0,869 & $<0,001$ & 0,005 & 0,901 \\
\hline Muut alkoholit ${ }^{4}$ & 3,38 & 2,79 & 3,27 & 2,82 & 0,215 & 0,128 & 0,450 & 0,156 \\
\hline Amm. N, g/kg N & 155 & 112 & 138 & 130 & 21,8 & \multicolumn{3}{|c|}{ Ei normaalisti jakautunut } \\
\hline Amm. N, g/kg N ${ }^{2}$ & 155 & 112 & 44 & 130 & 21,7 & \multicolumn{3}{|c|}{ Ei normaalisti jakautunut } \\
\hline
\end{tabular}

\footnotetext{
${ }^{1} \mathrm{PR}=$ ei säilöntäainetta (painorehu), $\mathrm{MH}=$ muurahaishappo, $\mathrm{NaHe}=$ heksametyleenitetramiinin ja natriumnitriitin seos, LAB = maitohappobakteeri Lactobacillus plantarum

${ }^{2}$ Vähennetty säilöntäaineessa lisätty typpi. Kaikki säilöntäaineessa lisätty N on laskettu korjatussa pitoisuudessa ammoniakkitypeksi, koska tarkkaa tietoa muuntumisosuudesta ei ole käytettävissä.

${ }^{3}$ Maitohappo + haihtuvat rasvahapot (etikka-, propioni-, isovoi-, voi-, isovaleriaana- , valeriaana- ja kapronihappo)

${ }^{4}$ Muut alkoholit: metanoli, propanoli, butanoli
} 